\title{
Rhododendron 'Candy Lights' and 'Lilac Lights'
}

\author{
Stan C. Hokanson, ${ }^{1}$ Steve McNamara, ${ }^{2}$ Kathy Zuzek, ${ }^{2}$ Nancy Rose,${ }^{3}$ \\ and Harold Pellett ${ }^{4}$ \\ University of Minnesota Department of Horticultural Science and Landscape \\ Arboretum, 1970 Folwell Avenue, St. Paul, MN 55108
}

Additional index words. deciduous azalea, plant breeding, cold hardiness

The University of Minnesota Woody Landscape Plant Breeding Program has been actively engaged in developing cold hardy deciduous azalea (Rhododendron subg. Pentanthra) cultivars since 1957 when the first species crosses were made. Since that time 13 cultivars have been released by the project (Rose et al., 2002; Rose and Pellett, 1994). The primary objective of the effort has been to develop cultivars that are sufficiently hardy for USDA Plant Hardiness Zone 4(United States National Arboretum, 2003). Herein, we describe the two most recent additions to the 'Lights' series of cold hardy deciduous azaleas.

\section{Origin}

'Candy Lights' and 'Lilac Lights' deciduous azaleas, tested as UMNAZ 315 and UMNAZ 193 respectively, were released by the University of Minnesota Woody Landscape Plant Breeding program to the wholesale nursery industry in 2000 and 2001, respectively. 'Candy Lights' resulted from a 1985 cross between Rhododendron atlanticum and a red-flowered Mollis hybrid azalea $(R$. ×kosteranum) referred to within the program as 'Dayton Red' (Fig. 1). 'Lilac Lights' resulted from a 1979 cross between $R$. canadense and an unnamed Mollis hybrid azalea ( $R$. ×kosteranum) (Fig. 1). 'Candy Lights' and 'Lilac Lights' were selected from seedling beds at the Horticultural Research Center in Excelsior, Minn., in 1989 and 1985, respectively, and subsequently evaluated in three plant plots at the Horticultural Research Center in Excelsior, Minn. (44 50' $\mathrm{N}$ latitude).

\section{Description}

'Candy Lights' is an upright, arching plant, somewhat taller than wide. The plant shows no signs of suckering despite the fact that the $R$. atlanticum parent is known to exhibit a stoloniferous growth habit in its native habitat. The original clonally propagated plants (19

Received for publication 9 May 2005. Accepted for publication 21 June 2005. Journal series paper 051210149 of the Dept. of Horticultural Science. This research was paid for in whole, or in part, by the Minnesota Agricultural Experiment Station. ${ }^{1}$ Assistant professor, author for correspondence. ${ }^{2}$ Research scientist.

${ }^{3}$ Former research scientist. Currently extension specialist, University of Minnesota Extension Service. ${ }^{4}$ Professor emeritus and director of the Landscape Plant Development Center, Mound, Minn. years old) average $1.9 \mathrm{~m}$ in height and 1.4 $\mathrm{m}$ in width. 'Candy Lights' produces flower trusses that are oval in shape measuring 9 to $10 \mathrm{~cm}$ in height by 9 to $10 \mathrm{~cm}$ in width, with five to nine flowers per inflorescence (Fig. 2). Flower petals are varying shades of light pink

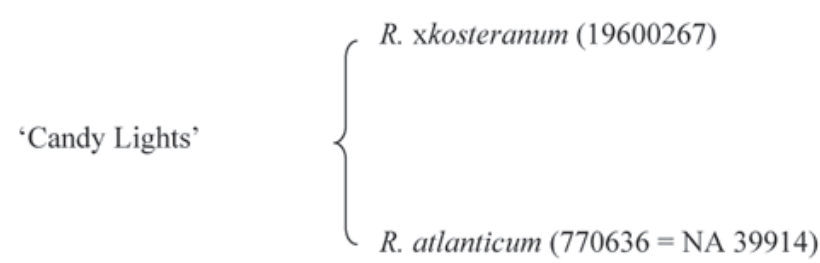
only $1.5 \mathrm{~m}$ in height. 'Lilac Lights' produces a five-lobed flower with two narrow, deeply (24 years old) measures $1.9 \mathrm{~m}$ tall by 2.4 $\mathrm{m}$ wide, clonally propagated plants grown in uncrowded, full sun conditions appear 600267)

R. atlanticum $(770636=$ NA 39914$)$
(RHS 62C, 68D, and 69A) with a darker rosy pink corolla tube (RHS 55A). The upper flower petal is yellow (RHS 13B). 'Candy Lights' brings pink back to the color spectrum of the Lights series of azaleas as an earlier release, 'Pink Lights', proved to be difficult to propagate in commercial quantities. Leaf color is a medium green (RHS 137A or 139A) (Royal Horticultural Society, 1995). In Excelsior, on average, first flowers emerge in the third week of May and the flowering is generally finished in the first week of June.

'Lilac Lights' plants assume a mounded form (Fig. 3). While the original seedling considerably shorter, $1.1 \mathrm{~m}$, and may grow to

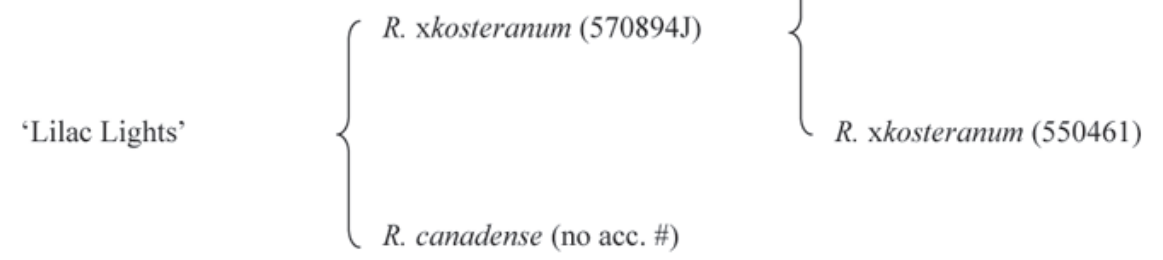

Fig. 1. Pedigree of UMNAZ 315, Candy Lights, and UMNAZ 193, 'Lilac Lights' deciduous azaleas.

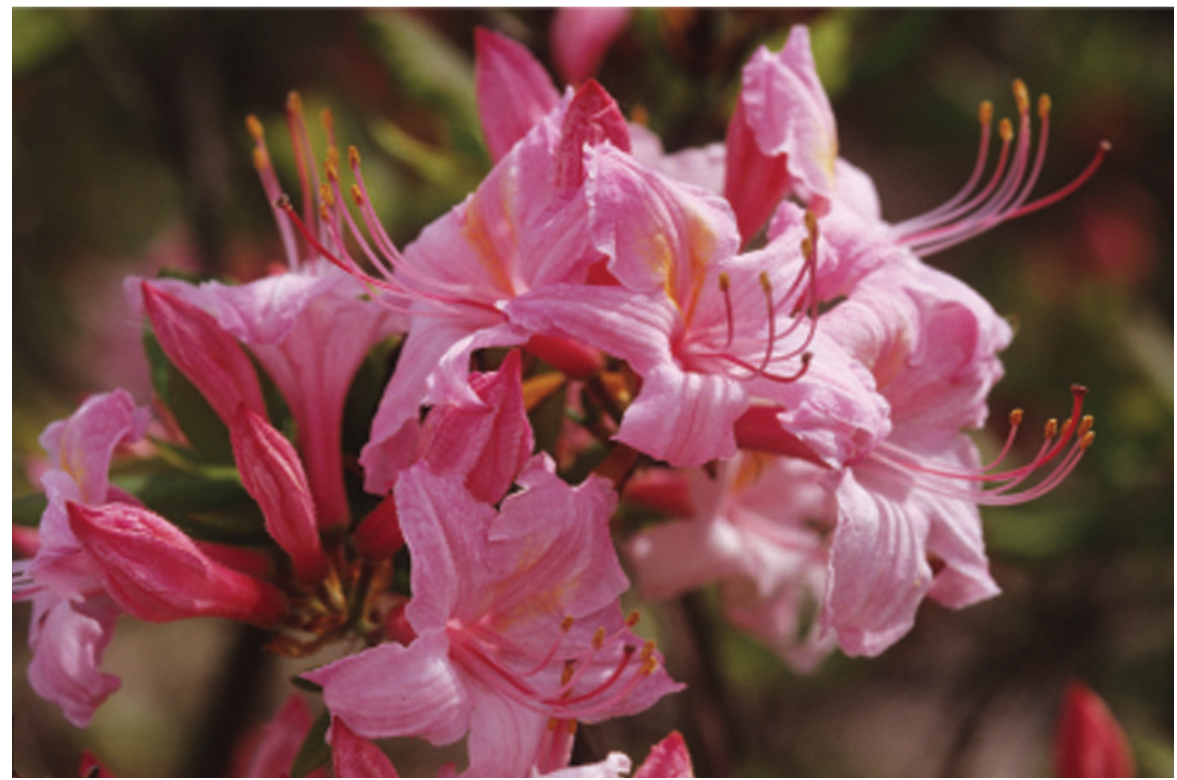

Fig. 2. 'Candy Lights' flower display. 


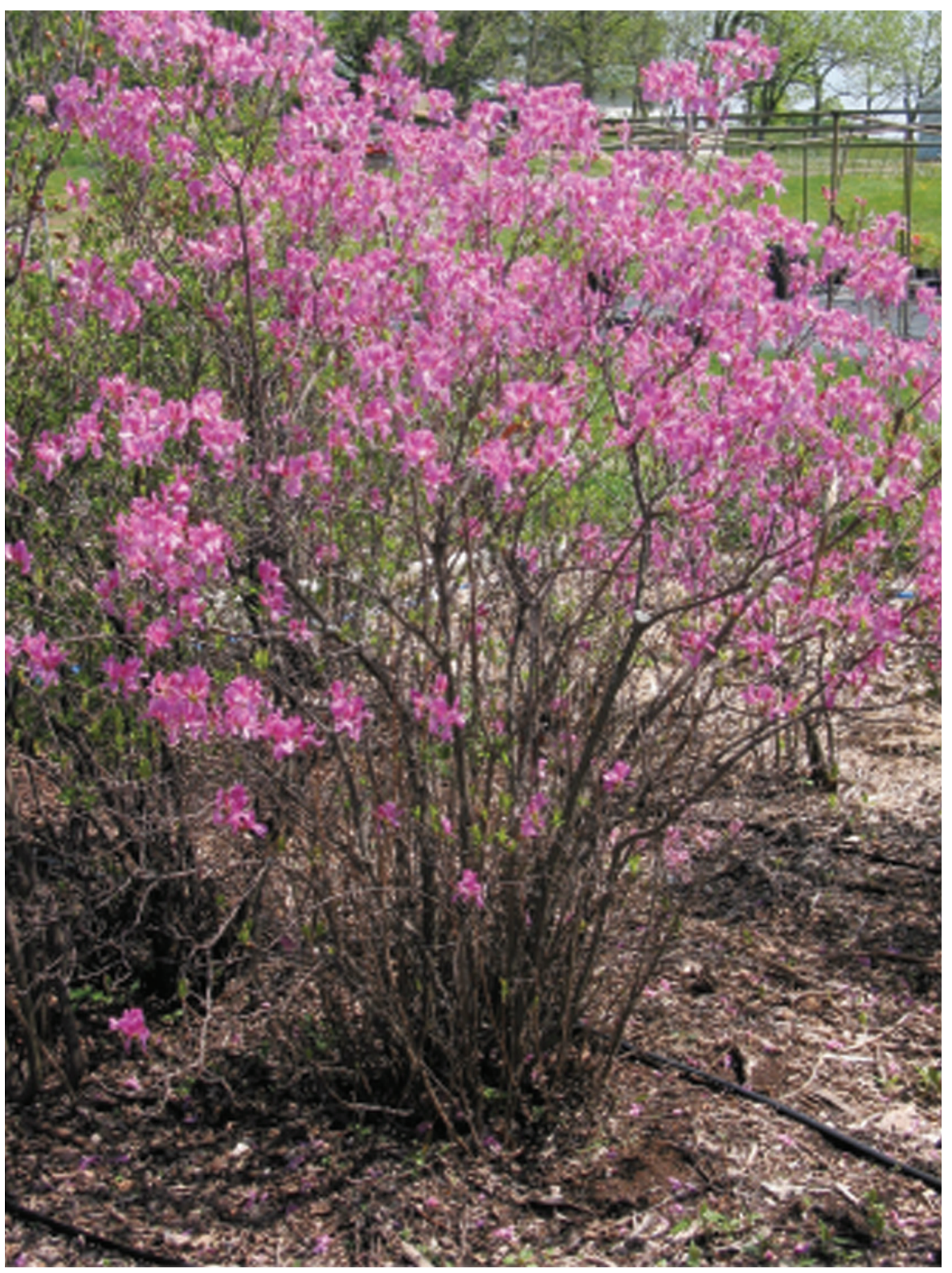

divided lower lobes and three wider, less deeply divided upper lobes (Fig. 3). 'Lilac Lights' has sturdier, more long-lived flower petals than a similar looking earlier release, 'Orchid Lights'. Inflorescences average 4.1 $\mathrm{cm}$ in length by $5.6 \mathrm{~cm}$ in width and contain seven to nine flowers per inflorescence. Individual corollas average $4.2 \mathrm{~cm}$ in diameter and $3.1 \mathrm{~cm}$ in length. Flower petals are lavender purple (RHS 74C) with a darker purple blotch (60A) on the upper petals. The filaments and style are pigmented in the purple-pink range (RHS 75A and 58A) respectively. Leaf color is a medium green (RHS 137A or B) (Royal

Horticultural Society, 1995). On average, in Excelsior, first flowers emerge in the second to third week of May with flowering quickly reaching full emergence in the third week of May. On average, flowering is finished in the last week of May.

\section{Adaptation}

Based on controlled laboratory freezing tests conducted as described previously, (McNamara et al., 2002) flower buds of 'Candy Lights' and 'Lilac Lights' can be considered hardy to $-34.4^{\circ} \mathrm{C}$ and $-31.7{ }^{\circ} \mathrm{C}$, respectively in

Table 1. Mean percentage of florets damaged out of six buds tested at $-31.7,-34.4$, and $-37.2{ }^{\circ} \mathrm{C}$ in controlled freeze tests conducted in Excelsior, Minn., in 3 different years for 'Candy Lights' and 'Lilac Lights' azaleas.

\begin{tabular}{|c|c|c|c|c|c|c|c|c|c|}
\hline \multirow[b]{4}{*}{ Cultivar } & \multicolumn{9}{|c|}{ Collection date } \\
\hline & \multicolumn{3}{|c|}{21 Jan. 1998} & \multicolumn{3}{|c|}{4 Feb. 2000} & \multicolumn{3}{|c|}{20 Jan. 2005} \\
\hline & \multicolumn{9}{|c|}{ Test temp $\left({ }^{\circ} \mathrm{C}\right)$} \\
\hline & -31.7 & -34.4 & -37.2 & -31.7 & -34.4 & -37.2 & -31.7 & -34.4 & -37.2 \\
\hline$\overline{\text { Candy Lights }}$ & --- & 23 & 93 & 24 & 22 & 57 & 5 & 28 & 62 \\
\hline Lilac Lights & --- & -- & -- & 21 & 62 & 70 & 28 & 78 & 81 \\
\hline
\end{tabular}

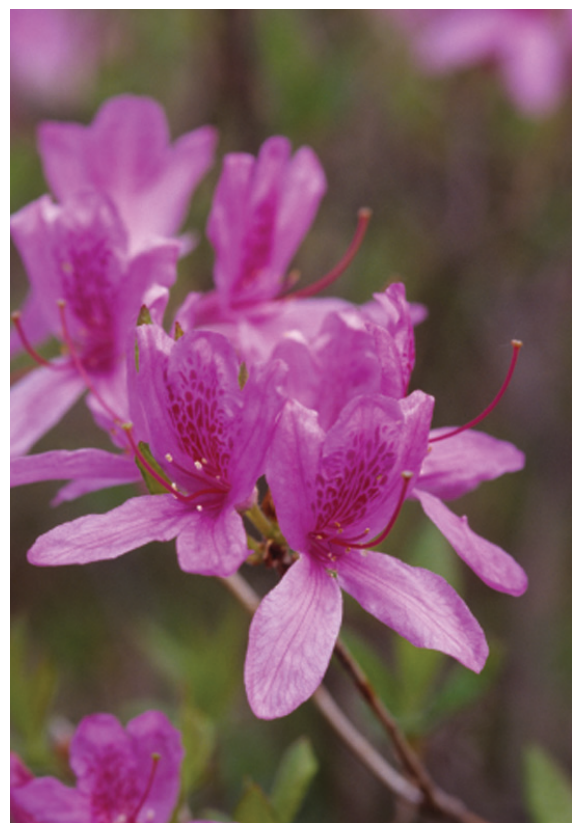

Fig. 3. Fourteen-year-old 'Lilac Lights' plant growing in evaluation beds in Excelsior, Minn. (left) and flower detail (above).

midwinter (Table 1). Although 'Candy Lights' exhibited $24 \%$ of florets with damage at -31.7 ${ }^{\circ} \mathrm{C}$ in the 2000 test (4 Feb. 2000), before the test a warming event occurred with daytime high temperatures reaching 2.8 and $2.2^{\circ} \mathrm{C}$ on 2 and 3 Feb., respectively. The warming event probably resulted in some deacclimation. It is likely that flower buds of both cultivars could be hardier in the absence of such deacclimation events. 'Candy Lights' and 'Lilac Lights' plants growing in the observation plots at the Horticultural Research Center have shown no obvious cold damage to either flower buds or vegetative tissue since being established in 1988 and 1985 respectively. Notable winter low temperatures at this site occurred in $1988\left(-37.2^{\circ} \mathrm{C}\right), 1994$ $\left(-35.6{ }^{\circ} \mathrm{C}\right)$, and $1996\left(-37.2^{\circ} \mathrm{C}\right)$.

Based on controlled freezing tests and observations of field grown plants in Excelsior, 'Candy Lights' and 'Lilac Lights' should be sufficiently winter hardy to be used successfully in landscapes in USDA Plant Hardiness Zone $4 \mathrm{a}\left(-34.4\right.$ to $\left.-31.7^{\circ} \mathrm{C}\right)$. Flower buds of 'Candy Lights' may be sufficiently hardy in USDA Zone $3 \mathrm{~b}\left(-37.2\right.$ to $\left.-34.4^{\circ} \mathrm{C}\right)$ locations in years without significant winter thaws and/or in locations protected from direct winds.

Both cultivars were grown in full sun exposures throughout the selection and evaluation process. As is the case for previous releases from the program, 'Candy Lights' and 'Lilac Lights' flower most heavily and exhibit less leaf disease when grown in full sun.

The two cultivars have been rated for foliage quality, primarily powdery mildew (PM) susceptibility, on a scale from $1=$ no disease occurrence to $5=\geq 75 \%$ leaf area infected. Plants were rated once in late August or early September, when most plants in the plots appeared symptomatic. Three leaves with average symptoms for the plant being evaluated were rated using the previously described scale. In previous research, we have determined 
that field grown deciduous azaleas generally showed more pronounced PM disease symptoms on the abaxial leaf surface and that this score is more indicative of the plants overall PM susceptibility and resistance (Long, 2005). In 2003, three 'Candy Lights' plants average foliage quality ratings were a 1.0 on the adaxial leaf surface and 1.3 on the abaxial surface. Based on an evaluation of four plants, 'Lilac Lights' rated a 1.8 on the adaxial leaf surface and 4.3 on the abaxial surface.

'Candy Lights' and 'Lilac Lights' leaf disease scores can be compared to 2003 adaxial and abaxial leaf disease scores for previously release cultivars from the program; 'Lemon Lights'(1.0/1.0), 'Northern Hi-Lights' (1.3/2.0), 'Mandarin Lights' (1.0/4.3), and 'White Lights' (1.0/2.0). Adaxial/abaxial leaf disease scores for the same cultivars were $1 / 1$, $1.7 / 2.7,1 / 2.3$, and $5 / 5$ in 2004 .

Selections and cultivars are also rated for overall plant appearance on a scale ranging from 1 equating with an excellent appearance, i.e., no disease or leaf blemish, to 3 equating with a poor appearance, i.e., prominent evidence of PM and/or other leaf diseases, including necrotic lesions, spotting, and/or defoliation. In 2003 'Candy Lights' and 'Lilac Lights' received overall appearance ratings of 1.7 and 2.8, respectively. In 2004, 'Candy Lights' and 'Lilac Lights' were rated as 2.0 and 3.0, respectively. These scores can be compared to overall plant appearance ratings for cultivars previously released from the program, 'Lemon
Lights', 'Northern Hi-Lights', 'Mandarin Lights', and 'White Lights', which received mean scores in 2003/2004 of 1.7/2.5, 1.7/2.3, $1.7 / 2.7$, and $1.8 / 3.0$ respectively.

Based on our observations in Excelsior, Minn., 'Candy Lights' and 'Lilac Lights' should be regarded as tolerant to and moderately susceptible to powdery mildew, respectively. 'Candy Lights' appears to be no more susceptible to powdery mildew, and equal in overall appearance, to previous deciduous azalea cultivars released from the program. 'Lilac Lights' is more susceptible to powdery mildew and has a lower appearance rating than deciduous azalea cultivars previously released from the program.

\section{Propagation}

'Candy Lights' and 'Lilac Lights' are propagated commercially by in vitro tissue culturing of shoot tips. Both cultivars can be propagated vegetatively by rooting softwood cuttings. Softwood cuttings collected in early to mid-June in Excelsior, dipped for $5 \mathrm{~s}$ in 8,000 ppm IBA (in 50\% ethanol), and stuck in 1 peat : 1 perlite media at $95-100 \%$ humidity will root successfully in two to three months. In the late summer and early fall, supplemental lighting set to achieve a 16-h photoperiod promotes new growth on the cuttings. Poor winter survival has been observed for cuttings that are allowed to go dormant before they initiate new growth.

\section{Availability}

'Candy Lights' and 'Lilac Lights' are being propagated by licensed propagators and are currently available at the wholesale level as liner and container plants. Nurseries interested in propagating these cultivars should contact the University of Minnesota Office of Patents and Technology Marketing, 450 McNamara Center, Minneapolis, MN 55415; (612) 6240550; ptm@umn.edu.

\section{Literature Cited}

Long, M.C. 2005. Field, garden and growth chamber assessments of deciduous azalea (Rhododendron subg. pentanthera G. Don) germplasm for powdery mildew (Microsphaera spp.) resistance. MS thesis. Univ. Minn., St. Paul, Minn.

McNamara, S., H. Pellett, M. Florkowska, and O. Lindstrom, Jr. 2002. Comparison of the cold hardiness of landscape tree and shrub cultivars growing at two disparate geographic locations. J. Environ. Hort. 20:77-81.

Rose, N. and H. Pellett. 1994. Rhododendron 'Northern Hi-Lights'. J. Environ. Hort. 12:179-180.

Rose, N., S. McNamara, H. Pellett, and K. Zuzek. 2002. Rhododendron 'Mandarin Lights, $R$. 'Lemon Lights', and $R$. 'Tri-Lights'. J. Environ. Hort. 20:62-63.

Royal Horticultural Society. 1995. Royal Horticultural Society colour chart. Royal Hort. Soc., London.

United States National Arboretum. 2003. USDA 1990 plant hardiness zone map. http://www. usna.usda.gov/Hardzone. 